\title{
Open Innovation and the Networked Firm
}

\author{
Working Paper No. 31
}

\section{Bruce Rasmussen}

\section{Pharmaceutical Industry Project Working Paper Series}

May 2007

Centre for Strategic Economic Studies

Victoria University of Technology

PO Box 14428 Melbourne VIC 8001 AUSTRALIA

Telephone +61399191340

Fax +61399191350

Contact email: bruce.rasmussen@vu.edu.au 


\title{
Open Innovation and the Networked Firm
}

\author{
Bruce Rasmussen
}

\section{Introduction}

The resource based view of Wernerfelt (1984), Barney $(1986,1991)$ and Deirickx and Cool (1989) suggests that firms can achieve sustainable competitive advantage through the accumulation of strategic assets that are hard to imitate, substitute or trade (Amit and Schoemaker 1993). It is also acknowledged however that start-ups often lack complementary assets (Teece 1986) and will seek them from alliance partners.

Equally there is scope within transactions cost economics (Williamson 1971, 1981, 1986, 1989) to consider the appropriateness of contracting across the boundary of the firm for products and services. While alliances have a different governance structure to the firm, the same tests of appropriateness may be applied to an alliance to explain its formation.

This paper considers the theoretical reasons for technology firms to be networked in order to be successful innovators. These theories suggest that it is not sufficient to consider the requirements for sustainable competitive advantage for a single firm but also necessary to take into account the conditions for sustainable competitive advantage in cooperation with other firms. Cooperation may involve jointly created product and even strategic assets. This raises the problem of the distribution of the value created and how small firms in particular may defend themselves against loss.

In this paper the unit of analysis moves from a focus on the individual firm to examining the behaviour of the firm in an alliance or network. In doing so, a set of related but independent theoretical concepts are employed. The open innovation paradigm provides something of a unifying framework by integrating these concepts within a networked view of innovation.

\section{Open innovation}

'Open innovation' (Chesbrough 2003; Chesbrough et al. 2006) is a framework that suggests that technology companies adopt a networked approach to innovation, in which companies exchange ideas and technologies and bring products to market through licensing and other alliance arrangements. There are two key aspects of the open innovation paradigm of particular relevance to this study. One is the networked nature of the innovation process and the other is the concept of the business model. As Chesbrough (2006a) puts it:

Open Innovation is a paradigm that assumes that firms can and should use external ideas as well as internal ideas, and internal and external paths to market, as they look to advance their technology. The business model utilizes both internal and external ideas to create value, while defining internal mechanisms to claim some portion of that value. (p1)

Chesbrough (2006a) claims eight points of difference for Open Innovation relative to prior theories of innovation. Perhaps the most important of these is the equal importance given to external knowledge, in comparison to internal knowledge as a 
source of innovation. Open Innovation is presented as the antithesis of the vertically integrated model of the firm in which new products are derived from internal R\&D. In the Open Innovation paradigm, the firm is an active participant in the 'market in technology', proactively acquiring sought after technologies and dispensing with surplus technologies through spin offs and licensing arrangements. The second is the centrality of the business model in converting $R \& D$ into commercial value. The business model provides the framework within which the firm operates. It selects projects that 'fit' and rejects those that don't. This helps identify technologies that should be licensed in and those that should be spun off. Other differences identified largely follow from these two key differences. This includes, a change in attitude to the knowledge landscape, which is viewed as rich and prospective, and recognising the economic value to the firm of proactive management of IP and of exporting internally developed, but underutilised, technology.

\section{Relationship to antecedent literature on alliances and networks}

The emphasis placed by 'open innovation' on the importance of networks and shared knowledge in the innovation process is not new. Networks have a central role in the concept of innovation systems (Freeman 1987; Lundvall 1992; Nelson 1993) and their importance has been highlighted by Arora and Gamberdella (1990), Pisano (1991) and Powell et al. (1996). The central role of technology alliances in the innovation process has been noted by Hagedoorn (1993) and others, in business strategy by Gomes-Casseres (1996) and in the partnership between pharmaceutical companies and dedicated biotechnology companies by Arora and Gamberdella (1990), Galambos and Sturchio (1998) and Orsengio et al. (2001) among others.

Powell has argued that inter firm collaboration can be viewed as a means of organizational learning (Powell 1998) through which core competencies can be enhanced. This raises entry barriers through restricting entry to networks, accelerates innovation and 'collaboration may itself become a dimension to the competition' (Powell 1998 p230). Powell (1998) argues that in innovation driven fields, firms are in engaged in learning races and that not only do firms learn from collaborations but they need to learn how to collaborate.

Empirical research suggests that participation in alliances has a positive effect on innovation output (Shan et al. 1994). Powell et al. (1996) demonstrates the value for innovative performance of firms in being deeply embedded in benefit rich networks, describing the network - not the individual firm as the locus of innovation. Furthermore Laursen and Salter (2006) illustrate the positive relationship between the external searches for new knowledge, until the point of decreasing returns is reached, and innovative performance.

The emphasis on alliances also reflects changes in the global business environment. For instance, Dunning, a prominent researcher of multinational enterprises since the 1950s, has described increased emphasis on cooperation between firms as 'alliance' capitalism. In his view this has been brought about by globalisation and a series of landmark technological advances (Dunning 1995).

The OECD has conducted a series of studies of innovation using alliances, networks and innovation systems (see for instance, OECD 1999, 2000, 2001, 2002) which produced the following useful definition of an alliance: 


\begin{abstract}
Strategic alliances take a variety of forms, ranging from arm's-length contract to joint venture. The core of a strategic alliance is an inter-firm co-operative relationship that enhances the effectiveness of the competitive strategies of the participating firms through the trading of mutually beneficial resources such as technologies, skills, etc. Strategic alliances encompass a wide range of inter-firm linkages, including joint ventures, minority equity investments, equity swaps, joint R\&D, joint manufacturing, joint marketing, long-term sourcing agreements, shared distribution/services and standards setting. (OECD 2000)
\end{abstract}

Hagedoorn (1993) has produced a comprehensive list derived from the literature on the motives for strategic alliance formation grouped under three headings. This list (see Table 1) includes motives that might be ascribed to both the resource based view and transaction cost economics. The need for complementary technologies and capturing tacit knowledge coincide with the approach of the former, while cost reductions, minimising risks and uncertainty speak more to the transaction cost economic approach. Motives such as internationalisation and globalisation are consistent with Dunning's views cited above about the changed business environment. These also relate to the resource based view however since global distribution capacities is one of the crucial complementary assets typically sought by start up technology companies.

Table 1. An overview of motives for (strategic) interfirm technology cooperation

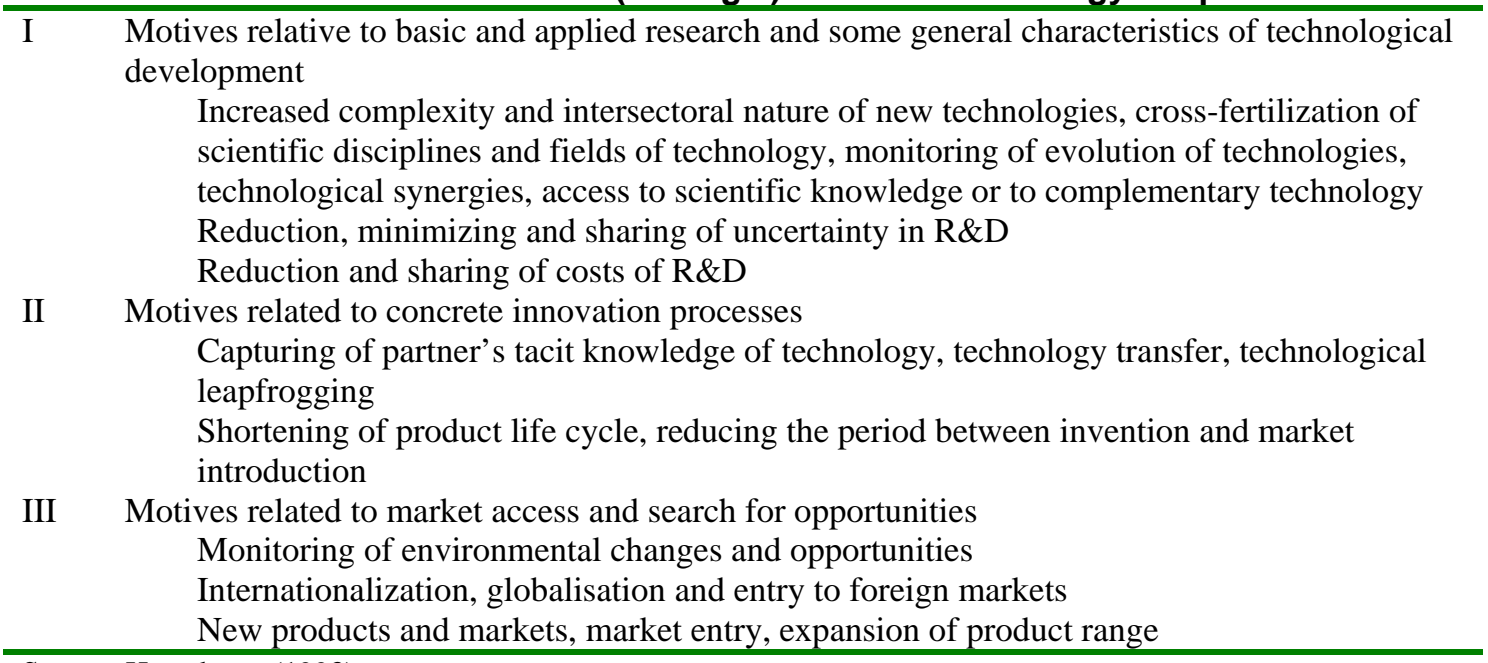

Source: Hagedoorn (1993).

\title{
Theoretical reasons for alliances
}

\section{Transaction cost economics and alliance governance structures}

Alliances provide an alternative to either internal integration or market contract. For transactions involving highly specific assets, internalisation may be preferred because of the high costs involved in haggling over the terms and contingent claims of contracts involving small numbers (Kogut 1988). However alliances provide a form of organisation through which a co-operative venture can be administered. The two firms would share ownership of the residual and control rights. Although it would be expected that there would be difficulties in sharing ownership, transaction cost economics predicts that this would be worthwhile provided that the costs of 
internalisation or the risks of contracting out were higher than an alliance. Kogut (1988), referring to joint ventures, suggests that such collaborations resolve:

...the high levels of uncertainty over the behaviour of the contracting parties when the assets of one or both parties are specialised to the transaction and the hazards of joint production are outweighed by the higher production or acquisition costs of 100\% ownership. (p 321)

From a transaction costs perspective, this suggests that the reasons for alliances are formed are to reduce the risks of contracting out and to offer a cheaper alternative to either joint production or outright ownership.

Effectively therefore, transaction cost economics identifies a set of issues that need to be addressed in the governance structures of any alliance. These focus on the need to control residual property rights and reduce opportunism. This predicts that alliances will have incentive arrangements that reduce tendencies towards opportunism. In alliances in which there is an 'R\&D party' which undertakes the research and a 'client party' which meets most of the expenses, it is common for alliance payments to be paid on achievement of milestones and for the real value of the alliance to be in the shared revenue, such as drug sales, received well after the conclusion of the R\&D phase. In such cases, both parties are equally 'hostage' to the successful outcome of the alliance (Hagedoorn et al. 2000).

Misuse of residual property rights can occur when knowledge obtained within one alliance is used to benefit another, formed perhaps with a competitor. This may be a real risk for any client party participating in an alliance to create a particularly valuable and inimitable strategic asset where the R\&D party can insist on nonexclusivity. It may be one of the reasons for such alliances to involve an equity investment, which provides the client with greater influence over the total operations of the R\&D firm.

\section{Complementary assets}

One of the key reasons for establishing an alliance, according to the resource based view is to acquire complementary assets (Teece 1986). In the resource based view, the firm's sustainable competitive advantage depends on its access to a portfolio of strategic assets. Not all these need be owned by the firm. Some can be accessed through alliances. For instance it is unlikely that a technology start up will have, in addition to its core technology, a full set of manufacturing, marketing and distribution services necessary to make and distribute its product. It may also require complementary technologies which it needs to combine with its own core technologies. For instance companies developing bioinformatics, which combines information technology and biotechnology, may need other technology companies to provide aspects of one or the other of these two technologies.

Not all complementary assets have the same level of specialisation. Many accounting firms should be able to provide financial services, but only a single firm may have the capacity to supply the technology necessary to complement an innovator's core technology. Teece (1986) has classified complementary assets into three types. He has distinguished between generic, specialised and co specialised complementary assets:

Generic assets are general purpose assets which do not need to be tailored to the innovation in question. Specialized assets are those where there is unilateral dependence between the 
innovation and the complementary asset. Co-specialized assets are those for which there is a bilateral dependence. (p289)

Acquiring access to these different types of assets through an alliance has implications for the relationship likely to be established by the alliance parties. In accessing specialised assets through an alliance, there is a high level of dependence between the innovation and the asset. Loss of access such as the termination of an alliance may have major implications for the innovation. An alliance to acquire co-specialised assets has a mutual dependency. In such an alliance the parties are interdependent. For instance, in a biopharmaceutical alliance between a drug discoverer and a pharmaceutical firm, the assets are likely to be co-specialised. The drug discoverer may need manufacturing and marketing support, while the pharmaceutical company needs the revenue from sales of the successfully developed drug, which it can distribute through its marketing channels. Termination is likely to have negative consequences for both parties. On the other hand, access to generic assets can be found in the market place without the need to establish an alliance.

\section{Alliances and the Dynamic Capabilities Approach}

The concept of dynamic capabilities relates to the need for a firm to adopt a corporate strategy, to constantly adjust and renew its capabilities in response to rapid technological change. Dynamic capabilities (Teece and Pisano 1994; Teece et al. 1997) are defined by Teece et al. (1997) 'as the firm's ability to integrate, build, and reconfigure internal and external competences to address rapidly changing environments' (p572). A component of this process of constant adjustment is the incorporation of new technologies into the firm through alliances.

In a related approach, Prahalad and Hamel (1990) suggested that missing competencies could be acquired through alliances at low cost. Quoting a case study of NEC, which used over 100 strategic alliances aimed at building competencies rapidly at low cost, managers were specifically tasked with internalising partner skills. This aspect of learning from alliances was incorporated by Kogut and Zander (1992) into their definition of a firm's 'combinative capability' as being the capability to 'synthesize and apply current and acquired knowledge (p384). They contemplated knowledge being sourced from both internal learning and external learning, such as acquisitions and joint ventures. The effectiveness of the process of knowledge transfer both inside and from outside the firm is considered central to the growth of firms by Kogut and Zander (1993) and depends on the degree to which the knowledge is difficult to understand and codify (p636). The effectiveness of this transfer and the ability of the firm to access and handle new knowledge can create the need for collaboration.

\section{Absorptive Capacity}

Related to the question of the capability of firms to learn from their alliances and collaborations, Cohen and Levinthal (1990) have defined the concept of 'absorptive capacity' as the capacity of large firms to take advantage of new technologies. This typically involves the willingness of such firms to invest in basic science in order to better understand new technologies and identify opportunities presented by emerging specialist technology firms. Accordingly (Granstrand et al. 1997) found that large companies are becoming more diverse in their technological knowledge platforms in order to explore and experiment with new technologies in order to take advantage of 
such opportunities. Both Merck and Eli Lilly provide examples of pharmaceutical firms using early contracts with biotechnology pioneers to learn more about biotechnology, thereby increasing their 'absorptive capacity' in the new technology (Galambos and Sturchio 1996).

The recent development of the open innovation paradigm reflects the perception that the innovation process has evolved from one dominated by large multi divisional, vertically integrated firms, to one in which both large and small firms each plays a significant role in a networked environment (Langlois 2003; Rothwell 1994). In this model importance is placed on the coupling of the specialised knowledge of small firms to the greater product development and distribution capabilities of large firms through licensing agreements, joint ventures and other alliance structures. In the view of Arora, Fosfuri and Gambardella (2001) this 'division of labour' has created a market in technology between upstream technology suppliers and downstream users.

Arora, Fosfuri and Gamberdella (2001) identify a series of changes in the markets for technology that have improved the ease with which technology can be transferred. In general, transferability is improved if the technology can be decomposed into independent tasks and commoditised, that is, if the technology can be embodied in a product that requires little tacit knowledge to use it.

This overview of the literature provides a set of theoretical reasons for alliance formation focussed on transaction cost economics, the resource based view and the related dynamic capabilities approach. Transaction cost economics focuses on the cost and risk reduction reasons for alliance formation, while the resource based view and related approaches, focuses on the acquisition of complementary assets, whether in the static framework of the resource based view, or the more time responsive, dynamic capabilities approach, involving alliances as a means of learning. The likelihood of a large firm successfully participating in an alliance is increased by learning strategies designed to increase in 'absorptive capacity'. The concept of complementary assets predicts that alliances with specialised or co specialised are likely to have quite different partner dependencies and impacts should they fail or be terminated. Finally the literature suggests that technology is becoming more codified and therefore easier to transfer, including through an alliance. On the other hand knowledge which is highly tacit and can be transferred only inside the firm is viewed as one of the reasons firms exist. These two apparently contradictory views help explain why some technology alliances are successful while others are not.

The reasons for alliances discussed in this review have been firm-centric. They have addressed the question of how the firm creates value from an alliance, such as how it supplements its own resources to create value or obtains assets at a lower cost or risk compared with either the open market or through integration. Even the open innovation paradigm with its emphasis on networked innovation through a focus on the value generated by internally and externally sourced knowledge and in particular by the active management of surplus to requirements knowledge and technologies, remains largely firm-centric. An exception is Vanhaverbeke and Cloodt's (2006) discussion of value networks and value constellations which contemplates the creation of value by the constellation and its distribution amongst participants including customers. 


\section{Creating and sharing value in alliances}

\section{The relational view}

In contrast to this firm centric view, Dyer and Singh (1998) specifically address the question of the value created in an alliance through the creation of 'joint assets'. Their so called 'relational view' suggests that the alliance or network may develop a joint asset, which may form the basis of a shared competitive advantage. They define a 'relational rent':

....as a supernormal profit jointly generated in an exchange relationship that cannot be generated by either firm in isolation and can only be created through the joint idiosyncratic contributions of the specific alliance partners... (p662)

Dyer and Singh argue that a number of factors will tend to increase the relational rents generated by an alliance. In general relational rents will be higher:

- the greater the value of the investment in alliance owned specific assets and the longer the alliance has been in existence

- the greater the investment by the partners in knowledge sharing routines and the greater the partner specific absorptive capacities

- the larger the proportion of synergy sensitive complementary resources devoted to the alliance, which are valuable rare and difficult to imitate. Generating rents from combining complementary assets requires experience on the part of the alliance parties to identify each other and to choose partners that are compatible.

- for alliances with more effective governance structures such as those that have informal self enforcing safeguards. Gulati (1998) emphasises the social origins of alliances and the embeddedness of firms within social networks that enhances trust between firms. With a history of alliance formation and a reputation at stake, partners will be less likely to exploit their counterpart's vulnerabilities within the alliance structure.

One risk for the partners is that others will simply imitate the partnering behaviour, eliminating any competitive advantage of the alliance (Dyer and Singh 1998, p671). Dyer and Singh (1998) offer a number of suggestions for mechanisms that will preserve the joint rents. These include partner scarcity that may inhibit others forming competing alliances. There may not be other potential partners with such a level of complementary resources or relational capability. Other reasons may arise from the physical attributes of the shared asset, its indivisibility or its interconnectedness across corporate boundaries.

Relational rents have a potentially large role in any innovative activity in which alliance formation and in particular the creation of joint assets is an important aspect. Not only is it important to understand from a theoretical point of view, the circumstances in which the value of relational rents are increased or are protected from erosion by imitators, but it is also necessary to be able to predict how the value is shared between the partners within the alliance.

\section{Importance of the IP Regime}

Teece (1986) addressed this question in his analysis of the impact of various appropriability regimes on the distribution of profits between innovator and imitators 
and/or the owners of the complementary assets that are specialised or co-specialised to the innovation.

In a tight appropriability regime innovators who contract for access to complementary assets will gain most of the value, although some sharing of profits may be necessary if the innovator is disadvantageously placed with respect to those assets. A small company will therefore be more likely to form an alliance when it is confident about the appropriability of its own innovation, i.e. where there is a strong IP regime, which will protect the innovation from expropriation by potential partners (Gans and Stern 2003). Alternatively the innovator may take the time necessary to integrate (or develop) those assets so as to guarantee a full profit share.

However if the appropriability regime is weak, Teece argues that the outcome will depend on the how the innovator or imitator is placed with respect to the owners of complementary assets. If such complementary assets are scarce then the innovator may be forced to concede a large share of the profits to the owners of the complementary assets. Should an imitator have better access to such assets then it is likely to gain greater benefits from the innovation than the innovator. As a corollary should the assets be specialised, but more generally available, then the innovator (or an imitator) will gain a better share of the profits.

Aghion and Tirole (1994) have used the framework of incomplete contracts to analyse the relationship between a 'research unit' and a 'customer' for the research in an alliance structure that places more emphasis on the value of the innovation. In such a framework, a 'research unit' is characterised as performing the creative task while the 'customer' who expects to benefit from the innovation, provides the financing. The framework is used to predict that research activities are more likely to be conducted in a research unit independent of the customer when the intellectual inputs are substantial relative to the capital inputs and the customer is in a weak position because of a scarcity of the research capability.

Lerner and Merges (1998) have used this framework to undertake an analysis of a small number of biotech alliances to determine the balance of control of the alliance between the biotech (research unit) and established pharmaceutical company (customer). Their main finding, in keeping with Aghion and Tirole, is that the biotechs ceded the least proportion of the control rights when their financial position is strongest. The study also examined which party was likely to control particular aspects of the alliances. Importantly the model predicted that the biotech, as the owner and developer of the knowledge base, was more likely to retain control over the patents and related litigation, emphasising the importance of IP as a strategic asset for the biotech. The pharmaceutical company was most likely to control the marketing and manufacturing aspects, as well as the power to terminate the alliance.

\section{Conclusions}

This paper has focussed on the theoretical reasons for alliances based in large part on the theories of the firm. As discussed both transaction cost economics and the resource based view of the firm offer reasons for firms establishing alliances and the concept of complementary assets in particular demonstrates how alliances can create value for the firm. The relational view offers a new perspective by demonstrating that an alliance can create joint assets and therefore the alliance, to some extent 
independent of the firm, can generate rents. For the individual firm it is essential to receive a share of these rents that is sustainable. Teece (1986) suggests that the appropriability of the innovation determines whether the innovator, the owner of complementary assets or an imitator receives the greatest share of these rents.

This paper has explored the theoretical aspect of one of two essential features of the open innovation paradigm - the reasons for innovating firms to participate in networks and alliances.

\section{References}

Aghion, P. and Tirole, J. 1994, 'The management of innovation', Quarterly Journal of Economics, vol. 109, no. 4, pp. 1185-1207.

Amit, R. and Shoemaker, P. 1993, 'Strategic assets and organizational rent', Strategic Management Journal, vol. 14, pp. 33-46.

Arora, A. and Gambardella, A. 1990, 'Complementarity and external linkages in biotechnology: The strategies of large firms in biotechnology', Journal of Industrial Economics, vol. 38, no. 4, pp. 361-379.

Arora, A., Fosfuri, A. and Gambardella, A. 2001, Markets for Technology: The Economics of Innovation and Corporate Strategy, MIT Press, Cambridge, Mass.

Barney, J. R. 1986, 'Strategic factor markets: Expectations, luck and business Strategy’, Management Science, vol. 32, pp. 1231-1241.

Barney, J. R. 1991, 'Firm resources and sustained competitive advantage', Journal of Management, vol. 17, pp. 99-120.

Chesbrough, H. 2003, Open Innovation: The New Imperative for Creating and Profiting from Technology, Harvard University Press, Cambridge, Mass.

Chesbrough, H. 2006a, 'Open innovation: A new paradigm for understanding industrial innovation', in Chesbrough et al. 2006.

Chesbrough, H., Vanhaverbeke, W. and West, J. (eds) 2006, Open Innovation: Researching a New Paradigm, Harvard University Press, Cambridge, Mass.

Cohen, W. M. and Levinthal, D.A. 1990, 'Absorptive capacity: A new perspective on learning and innovation', Administrative Science Quarterly, vol. 35, pp. 128-152.

Dierickx, I. and Cool, K. 1989, 'Asset stock accumulation and sustainability of competitive advantage’, Management Science, 35, 1504-1511.

Dunning, J. 1995, 'Reappraising the eclectic paradigm in an age of alliance capitalism’, Journal of International Business Studies, vol. 26, no. 3, pp. 461-491.

Dyer, J. and Singh, H. 1998, 'The relational view: Cooperative strategy and sources of interorganizational competitive advantage', Academy of Management Review, vol. 23, no. 4, pp. 660-679.

Freeman C. 1987, Technology Policy and Economic Performance: Lessons from Japan, Pinter, London.

Galambos, L. and Sturchio, J. 1996, Pharmaceutical firms and the transition to biotechnology: A study in strategic innovation', Business History Review, vol. 72, no. 2, pp. 250-278. 
Galambos, L. and Sturchio, J. 1998, 'Pharmaceutical firms and the transition to biotechnology: A study in strategic innovation’, Business History Review, vol. 72, pp. 250-279.

Gans, J. S. and Stern, S. 2003, 'The product market and the "market for ideas": Commercialization strategies for technology entrepreneurs', Research Policy, vol. 32, pp. 333-350.

Gomes-Casseres, B. 1996, The Alliance Revolution: The New Shape of Business Rivalry, Harvard University Press, Cambridge, Mass.

Granstrand, O., Patel, P. and Pavitt, K. (1997), 'Multi-technology corporations: Why they have "distributed” rather than "distinctive core” competencies', California Management Review, 39, 8-25.

Gulati, R. 1998, 'Alliances and networks', Strategic Management Journal, vol. 19, pp. 293-317.

Hagedoorn, J. 1993, 'Understanding the rationale of strategic technology partnering: Inter-organizational modes of cooperation and sectoral differences', Strategic Management Journal, vol. 14, pp. 371-385.

Hagedoorn, J., Link, A., Vonortas, N. 2000, 'Research partnerships', Research Policy, vol. 29, pp. 567-586.

Kogut, B. 1988, 'Joint ventures: Theoretical and empirical perspectives', Strategic Management Journal, vol. 9, pp. 319-332.

Kogut, B. and Zander, U. 1992, 'Knowledge of the firm, combinative capabilities, and the replication of technology', Organization Science, vol. 3, no. 3, pp. 383-397.

Kogut, B. and Zander, U. 1993, 'Knowledge of the firm and the evolutionary theory of the multinational corporation', Journal of International Business Studies, 4th quarter, pp. 625-644.

Langlois, R. N. 2003, 'The vanishing hand: The changing dynamics if industrial capitalism', Industrial and Corporate Change, vol. 12, pp. 351-385.

Laursen, K. and Salter, A. 2006, 'Open innovation: The role of openness in explaining innovation performance among UK manufacturing firms’, Strategic Management Journal, vol. 27, pp. 131-150.

Lerner, J. and Merges, R. 1998, 'The control of strategic alliances: An empirical analysis of biotechnology collaborations', NBER Working Paper No. 6014, National Bureau of Economic Research, Cambridge, Mass.

Lundvall, B. 1992, National Systems of Innovation, Towards a Theory of Innovation and Interactive Learning, Pinter, London.

Nelson, R. 1993, National Innovation Systems: A Comparative Analysis, Oxford University Press, Oxford.

OECD 1999, Managing National Innovation Systems, Paris.

OECD 2000, International Strategic Alliances: Their Role in Industrial Globalisation, Paris.

OECD 2001, Innovative Networks Co-operation in National Innovation Systems, Paris. 
OECD 2002, Dynamising National Innovations Systems, Paris

Orsenigo, L., Pammolli, F. and Riccaboni, M. 2001, 'Technological change and network dynamics Lessons from the pharmaceutical industry', Research Policy, vol. 30, pp. 485-508.

Pisano, G.P. 1991, 'The governance of innovation: Vertical integration and collaborative arrangements in the biotechnology industry', Research Policy, vol. 20, pp. 237-249.

Powell, W., 1998, 'Learning from collaboration: Knowledge and networks in the biotechnology and pharmaceutical industries', California Management Review, vol. 40, no. 3, pp. 228-240.

Powell, W., Koput, K. and Smith-Doerr, L. 1996, 'Interorganizational collaboration and the locus of innovation: Networks of learning in biotechnology', Administrative Science Quarterly, vol. 41, pp. 116-145.

Prahalad, C. and Hamel, G. 1990, 'The core competence of the corporation', Harvard Business Review, May-June, pp. 79-91.

Rothwell, R. 1994, 'Towards the fifth-generation innovation process', International Marketing Review, vol. 11, pp. 7-31.

Shan, W., Walker, G. and Kogut, B. 1994, 'Interfirm cooperation and startup innovation in the biotechnology industry', Strategic Management Journal, vol. 15, pp. 387-394.

Teece, D. J. 1986, 'Profiting from technological innovation: Implications for integration, collaboration, licensing and public policy’, Research Policy, vol. 15, no. 6, pp. 285-305.

Teece, D. J. and Pisano, G. 1994, 'The dynamic capabilities of firms: An introduction’, Industrial and Corporate Change, vol. 3, no. 3, pp. 537-556.

Teece, D., Pisano, G. and Shuen, A. 1997, 'Dynamic capabilities and strategic management’, Strategic Management Journal, vol. 18, no. 7, pp. 509-533.

Vanhaverbeke, W. and Cloodt, M. 2006, 'Open innovation in value networks', in H. Chesbrough, W. Vanhaverbeke and J. West (eds), Open Innovation: Researching a New Paradigm, Oxford University Press, Oxford, pp. 258-281.

Wernerfelt, B. 1984, 'A resource-based view of the firm', Strategic Management Journal, vol. 5, pp. 171=180.

Williamson, O. 1971, 'The vertical integration of production: Market failure considerations’, American Economic Review, vol. 61, no. 2, pp. 112-123.

Williamson, O. 1981, 'The modern corporation: Origins, evolution, attributes', Journal of Economic Literature, vol. 19, December, pp. 1537-1568.

Williamson, O. 1986, Economic Organization, New York University Press, New York.

Williamson, O. 1989, 'Transaction cost economics', in R. Schmalensee and R. Willig (eds), Handbook of Industrial Organization, North Holland, Amsterdam. 